\title{
Erratum to: The Usefulness of Critical Pathway in Laparoscopic Cholecystectomy
}

Jae Uk Chong, M.D. ', Jung Bum Choi, M.D. ${ }^{1}$, Mi Ae Seo, R.N. ${ }^{2}$ Su Ji Lee, R.N. ${ }^{2}$, Ja Hye Cheon, M.PH. ${ }^{3}$, Kyung Sik Kim, M.D. ${ }^{1}$

${ }^{1}$ Department of Surgery, Yonsei University College of Medicine, ${ }^{2}$ Division of Nursing, ${ }^{3}$ Department of Quality Improvement (Qll, Severance Hospital, Seoul, Korea

Corresponding author

Kyung Sik Kim

Department of Surgery, Yonsei University College of Medicine, 50 Yonsei-ro, Seodaemun-gu, Seoul 03722, Korea

Tel: +82-2-2228-2125, Fax: +82-2-313-8289, E-mail: kskim88@yuhs.ac

This is an Open Access article distributed under the terms of the Creative Commons Attribution Non-Commercial License (http:// creativecommons.org/licenses/by-nc/4.0/) which permits unrestricted non-commercial use, distribution, and reproduction in any medium, provided the original work is properly cited.

Copyright @ 2016 The Journal of Minimally Invasive Surgery. All rights reserved.

J Minim Invasive Surg 2016; 19(2): 57-62

Name of hospital correction on page 58 and page 60

It was printed as

$\mathrm{OOO}$ 병원

Authors requested to change the name of the hospital to proper name.

Hospital name should be corrected as following.

Corrected hospital name

세브란스 병원 